\title{
Bingöl Koşullarında Bazı Adi Fiğ Hat ve Çeşitlerinin (Vicia sativa L.) Tohum Verimi, Kes Verimi ve Kes Kalitesi Açısından Değerlendirilmesi
}

\author{
Erdal ÇAÇAN ${ }^{1}$, Mahmut KAPLAN $^{2}$, Kağan KÖKTEN ${ }^{3}$, Halit TUTAR $^{3}$
}

ÖZET: Bu çalışma, Bingöl koşullarında bazı adi fĭ̆ hat ve çeşitlerinin tohum verimi, kes verimi ve kes kalitesini belirlemek amacıyla 2014-2015 yılları arasında iki yıl süreyle yürütülmüştür. Çalışmada materyal olarak 21 adet adi fiğ hat ve çeşidi kullanılmıştır. Tesadüf blokları deneme desenine göre kurulan araştırmada; tohum verimi, kes verimi, bin tane ağırlığı, ham kül, ham protein oranı, ham protein verimi, asit deterjanda çözünmeyen lif (ADF), nötral deterjanda çözünmeyen lif (NDF), sindirilebilir kuru madde (SKM), kuru madde tüketimi (KMT) ve nispi yem değerlerine (NYD) ilişkin veriler ele alınmıştır. Araştırma sonucunda; tohum verimi 38.8-94.8 kg da ${ }^{-1}, \mathrm{kes}^{2}$ verimi 105.7-289.8 $\mathrm{kg} \mathrm{da}^{-1}$, bin tane ağırl $\breve{g ̆}_{1} 37.9-56.3 \mathrm{~g}$, ham kül \%9.4-15.3, ham protein oranı \%8.1-12.4, ham protein verimi 12.1-31.1 $\mathrm{kg} \mathrm{da}^{-1}$, ADF \%29.5-37.3, NDF \%42.0-51.4, SKM \%59.8-65.9, KMT \%2.37-2.89 ve NYD 111.2-147.1 arasında değişmiştir. Bu parametreler açısından; Hat-1, GAP-2604, GAP-61721, Soner ve Alper genotiplerinin Bingöl ekolojik koşullarında üstün özellikler göstererek öne çıktığı tespit edilmiştir.

Anahtar kelimeler: Adi fĭ̆g, kes verimi, kes kalitesi, korelasyon

\section{Evaluation of Some Common Vetch (Vicia sativa L.) Line and Cultivars in Terms of Seed Yield, Straw Yield and Straw Quality in Bingöl Conditions}

\begin{abstract}
This study was conducted to determine the seed yield, straw yield and quality of common vetch lines and cultivars for two years between 2014 and 2015 in Bingöl conditions. In the research; 21 different common vetch lines and cultivars were used as material. The study was carried out according to the randomized block design. In the study; seed yield, straw yield, thousand grain weight, crude ash, crude protein, crude protein yield, acid detergent fiber (ADF), neutral detergent fiber (NDF), digestible dry matter (DDM), dry matter intake (DMI) and relative feed value (RFV) characteristics were investigated. In the results of research; seed yield, straw yield, thousand grain weight, crude ash, crude protein, crude protein yield, ADF, NDF, DDM, DMI and RFV values ranged from 38.8-94.8 $\mathrm{kg} \mathrm{da}^{-1}$, 105.7-289.8 $\mathrm{kg} \mathrm{da}^{-1}, 37.9-56.3 \mathrm{~g}, 9.4-15.3 \%, 8.1-12.4 \%, 12.1-31.1 \mathrm{~kg} \mathrm{da}^{-1}, 29.5-$ $37.3 \%, 42.0-51.4 \%, 59.8-65.9 \%, 2.37-2.89 \%$ and $111.2-147.1$ respectively. In terms of the examined parameters; the Hat-1, GAP-2604, GAP-61721, Soner and Alper genotypes were found to be superior over the others in Bingöl ecological conditions.
\end{abstract}

Keywords: Common vetch, straw yield, straw quality, correlation

\footnotetext{
Erdal ÇAÇAN (0000-0002-9469-2495), Bingöl Üniversitesi, Genç Meslek Yüksekokulu, Bitkisel ve Hayvansal Üretim Bölümü, Bingöl, Türkiye

Mahmut KAPLAN (0000-0002-6717-4115), Erciyes Üniversitesi, Ziraat Fakültesi, Tarla Bitkileri Bölümü, Kayseri, Türkiye

Kağan KÖKTEN (0000-0001-5403-5629), Halit TUTAR (0000-0002-9341-3503), Bingöl Üniversitesi, Ziraat Fakültesi,

Tarla Bitkileri Bölümü, Bingöl, Türkiye

Sorumlu yazar/Corresponding Author: Erdal ÇAÇAN, erdalcacan@gmail.com
} 


\section{GİRİŞ}

Genel olarak, ot ve tohum elde etmek amaciyla yetiştirilen fiğler, besin içeriklerinin çok yüksek olması sebebiyle hayvan besleme açısından yem değeri yüksek olan kıymetli bitkilerdir (Kurt, 2012). Fi ̆ (Vicia) cinsine ait dünyanın 1lıman bölgelerine yayılmış 150 kadar tür bulunmakta olup, bunlardan bir tanesi de adi fi $\breve{g}$ (Vicia sativa) türüdür (Er ve ark., 2011; Ekiz ve ark., 2011; Kurt, 2012).

Adi fiğ otu çok lezzetli ve besleyicidir. Her türlü hayvanın beslenmesinde başarı ile kullanılır (Açıkgöz, 2011). Yurdumuzda en fazla yetiştirilen fï̆ türü adi fiğdir. Otu besleyici bir hayvan yemidir. Fiğ tanesi kırılmak suretiyle kesif yem olarak hayvanlara yedirilir. Fi $\breve{g}$ tek yıllık bir yem bitkisi olduğu için ekim nöbeti bitkisi, yeşil gübre bitkisi, örtü bitkisi ve silo yemi olarak da yaygın bir şekilde kullanılır (Ekiz ve ark., 2011).

2016 yılı verilerine göre ülkemizde adi fiğgen dane amaçlı olarak 391560 dekarlık alanda 49001 ton üretim elde edilmektedir. Dekar başına dane verimi ise $125 \mathrm{~kg}$ 'dır. Bingöl iline ait istatistiki bir veri bulunmamaktadır. Bingöl iline en yakın il olan Elazı $\breve{g}$ ilinde ise adi fiğ için ortalama dane veriminin ise $96 \mathrm{~kg} \mathrm{da}^{-1}$ olduğu bildirilmektedir (Anonim, 2017). Tane üretimi için hasat edilen fiğden, harman sonunda elde edilen fiğ samanı da (kes) hayvanlar tarafından sevilerek yenen bir yemdir (Açıkgöz, 2001; Ekiz ve ark., 2011).

Ülkemizde adi fiğlerin ot verimi, tohum verimi ve ot (kuru ot) kalitesi ile ilgili olarak (Karadağ ve Büyükburç, 2004; Çil ve ark., 2006; Erdurmuş ve ark., 2010; Babat ve Anlarsal, 2011; Kökten, 2011; Seydoşoğlu, 2014; Temel ve ark., 2015) bir çok araştırma yürütülmüştür. Ancak adi fiğlerde tohum verimi elde edildikten sonra geriye kalan samanın (kes) yem değeri açısından sahip olduğu kalitenin tespitine yönelik olarak yürütülen çalışmalar, yok denecek kadar az sayıdadır.
Bundan hareketle, Bingöl ekolojik koşullarında 21 adet adi fiğ hat ve çeşidinin tohum ve kes verimininin tespit edilmesi, tohumu alındıktan sonra geriye kalan keslere ait kalite özelliklerinin ortaya çıkarılması bu çalışmanın amacını oluşturmuştur.

\section{MATERYAL VE YÖNTEM}

$\mathrm{Bu}$ araştırma, Bingöl Üniversitesine ait uygulama ve araştırma alanında, kuru şartlarda ve iki y1l süreyle (2014-2015) yürütülmüştür. Araştırmada; 10 adet adi fiğ hattı ve 11 adet adi fĭg çeşidi olmak üzere toplam 21 adet adi fiğ genotipi kullanılmıştır. Çalışmada kullanılan genotipler ile temin edildikleri kuruluşlar Çizelge 1'de verilmiştir.

Bingöl iline ait bazı iklim verileri Meteoroloji Müdürlüğünden temin edilmiştir. Bingöl ilinin uzun yıllar ilk altı aylık ortalama sıcaklı ğ $8.4{ }^{\circ} \mathrm{C}$ (2014 yılı için $8.2^{\circ} \mathrm{C}, 2015$ yılı için $8.5^{\circ} \mathrm{C}$ ), toplam yă̆ış miktarı $612.6 \mathrm{~mm}$ (2014 yılı için $620.3 \mathrm{~mm}$, 2015 yılı için $604.8 \mathrm{~mm}$ ) ve ortalama nispi nem değeri ise \%61.9 (2014 yılı için \%62.2, 2015 yılı için \%61.5)'dur. Çizelge 2'de verilen 2014 ve 2015 yıllarına ait ilk altı aylık iklim verilerine bakıldı ğında; uzun yıllar ortalamasının üzerinde sicaklık, uzun yıllar ortalamasına yakın nispi nem değeri ve uzun yıllar ortalamasının altında bir yağış miktarının alındığı görülmektedir.

Araştırma alanından alınan toprak örnekleri Bingöl Üniversitesi Ziraat Fakültesi ToprakBitki Analiz Laboratuvarında analiz ettirilmiştir. Analiz sonuçları daha önce belirlenen sınırlar kapsamında değerlendirilmiştir (Sezen, 1995; Karaman, 2012). Bu değerlendirme neticesinde; toprak yapısının tınlı, $\mathrm{pH}$ 'sının hafif asidik (6.37), tuzsuz (\%0.0066), organik madde (\%1.26), kireç $(\% 0.15)$ ve potasyum oranının az $(24.45 \mathrm{~kg} / \mathrm{da})$ ve fosfor oranının orta $(7.91 \mathrm{~kg} / \mathrm{da})$ olduğu tespit edilmiştir. 
Çizelge 1. Araştırmada Kullanılan Adi Fiğ Hat ve Çeşitleri ve Sağlandığı Kuruluşlar

\begin{tabular}{lllll}
\hline No & \multicolumn{1}{c}{ Çeşitler } & \multicolumn{1}{c}{ Sağlandığı Kuruluş } & \multicolumn{1}{c}{ Hatlar } & \multicolumn{1}{c}{ Sağlandığı Kuruluş } \\
\hline 1 & Dicle & GAP Ulus.Tar.Arş.Eğt.Mrk.Müd. & Hat-1 & GAP Ulus.Tar.Arş.Ĕğt.Mrk.Müd. \\
2 & Soner & GAP Ulus.Tar.Arş.Eğt.Mrk.Müd. & Hat-2 & GAP Ulus.Tar.Arş.Eğt.Mrk.Müd. \\
3 & Görkem & Dicle Üniversitesi Ziraat Fak. & Hat-7 & GAP Ulus.Tar.Arş.Eğt.Mrk.Müd. \\
4 & Kralkızı & Dicle Üniversitesi Ziraat Fak. & Hat-8 & GAP Ulus.Tar.Arş.Eğt.Mrk.Müd. \\
5 & Alper & Tarım İşletmeleri Genel Müd. & Hat-13 & GAP Ulus.Tar.Arş.Ĕğt.Mrk.Müd. \\
6 & Selçuk-99 & Tarım İşletmeleri Genel Müd. & Hat-17 & GAP Ulus.Tar.Arş.Eğt.Mrk.Müd. \\
7 & Cumhuriyet-99 & Tarım İşletmeleri Genel Müd. & GAP61721 & GAP Ulus.Tar.Arş.Eğt.Mrk.Müd. \\
8 & Kubilay-82 & Ege Tarımsal Araştırma Enst. Müd. & GAP 2604 & GAP Ulus.Tar.Arş.Ĕğt.Mrk.Müd. \\
9 & Uludağ & Uludağ Üniversitesi Ziraat Fak. & GAP2490 & GAP Ulus.Tar.Arş.Eğt.Mrk.Müd. \\
10 & Özveren & Doğu Akdeniz Tar. Arş.Enst.Müd. & GAP59998 & GAP Ulus.Tar.Arş.Eğt.Mrk.Müd. \\
11 & Alınoğlu-2001 & Tarla Bitkileri Mrk.Arş.Enst.Müd. & & \\
\hline
\end{tabular}

Çizelge 2. Bingöl İline Ait Bazı İklim Verileri

\begin{tabular}{lcccccc}
\hline \multirow{2}{*}{ AYLAR } & \multicolumn{2}{c}{ Ortalama Sicaklık $\left({ }^{\circ} \mathbf{C}\right)$} & \multicolumn{2}{c}{ Toplam Yağıș (mm) } & \multicolumn{2}{c}{ Ortalama Nispi Nem (\%) } \\
\cline { 2 - 7 } & $\mathbf{2 0 1 4}$ & $\mathbf{2 0 1 5}$ & $\mathbf{2 0 1 4}$ & $\mathbf{2 0 1 5}$ & $\mathbf{2 0 1 4}$ & $\mathbf{2 0 1 5}$ \\
\hline Ocak & -0.4 & 1.8 & 143.1 & 147.2 & 71.3 & 75.1 \\
\hline Şubat & 2.0 & 1.9 & 82.3 & 119.8 & 57.7 & 74.4 \\
\hline Mart & 8.6 & 5.5 & 83.5 & 155.3 & 62.9 & 66.9 \\
\hline Nisan & 13.2 & 10.7 & 41.6 & 66.7 & 53.3 & 60.1 \\
\hline Mayıs & 17.2 & 16.4 & 63.2 & 21.2 & 52.1 & 53.9 \\
\hline Haziran & 22.3 & 22.6 & 25.9 & 8.1 & 36.9 & 38.4 \\
\hline Toplam/Ortalama & $\mathbf{1 0 . 5}$ & $\mathbf{9 . 8}$ & $\mathbf{4 3 9 . 6}$ & $\mathbf{5 1 8 . 3}$ & $\mathbf{5 5 . 7}$ & $\mathbf{6 1 . 5}$ \\
\hline
\end{tabular}

Tarla denemesi, her iki yılda da Nisan ayının ilk haftasında önce pulluk, sonra kültivatör ve tapan çekilen arazide tesadüf blokları deneme desenine göre üç tekerrürlü olacak şekilde kurulmuştur. Denemede parsel boyları $5 \mathrm{~m}$, sira arası mesafe 20 $\mathrm{cm}$ ve her parselde 6 sıra olacak şekilde el markörü yardımıyla ekim yapılmıştır. Ekimde dekara $8 \mathrm{~kg}$ tohumluk kullanılmıştır. Ekim ile birlikte dekara saf madde üzerinden $4 \mathrm{~kg}$ azot $(\mathrm{N})$ ve $10 \mathrm{~kg}$ fosfor $\left(\mathrm{P}_{2} \mathrm{O}_{5}\right)$ gübresi verilmiştir.

Alt1 sıra olarak ekimi yapilan her parselin 3 sırası tohum elde etmek amacıyla bırakılmıştır. Tohum amaçlı hasat, her iki yılda da bitkilerin en alt baklaların tamamen olgunlaştı ̆̆ Temmuz ayının ilk haftasında yapılmıştır. Tohum amaçlı hasat 
edilen parseller harman edilerek tane verimi ve kes verimi elde edilmiştir.

Her çeşitten 400 adet tohum tartılarak bin tane ağırlıkları elde edilmiştir. Her çeşidin, tohumu alındıktan sonra geriye kalan kesi $1 \mathrm{~mm}$ elek çapına sahip değirmende ögütülerek analizlerde kullanılmıştır. Yemlerin ham kül içeriği 550 ${ }^{\circ} \mathrm{C}$ 'de 8 saat kül fırınında yakılarak saptanmıştır. Örneklerin, azot (N) içeriğinin saptanmasında Kjeldahl metodundan yararlanılmıştır.

Azot oranı 6.25 ile çarpılarak ham protein oranı hesaplanmıştır (AOAC, 1990). Nötral deterjanda çözünmeyen lif (NDF) ve asit deterjanda çözünmyen lif (ADF) oranları, ANKOM 200 Fiber Analyzer (ANKOM Technology Corp. Fairport, NY, USA) cihazı kullanılarak tespit edilmiştir (Van Soest et al., 1991).

Sindirilebilir kuru madde (SKM=88.9 - $(0.779$ $\mathrm{x} \% \mathrm{ADF})$ ), kuru madde tüketimi (KMT=120 / $\% \mathrm{NDF})$ ve nispi yem değerleri $(\mathrm{NYD}=(\mathrm{SKM} \mathrm{x}$ KMT) / 1.29) ise hesaplanarak elde edilmiştir (Morrison, 2003).

Araştırma sonuçları, JUMP istatistik paket programı kullanılarak tesadüf blokları deneme desenine göre varyans analizine tabi tutulmuştur. İstatistiksel olarak önemli çıkan sonuçlar \%1 seviyesinde Tukey testi ile karşılaştırılmıştır.

Araştırmada incelenen özellikler arasındaki ilişkileri belirlemek için korelasyon katsayıları hesaplanmıştır (Kalaycı, 2005).

\section{BULGULAR VE TARTIŞMA}

Adi fiğ hat ve çeşitlerinin tohum verimi, kes verimi, ham kül, ham protein oranı, asit deterjanda çözünmen lif, nötral deterjanda çözünmeyen lif, sindirilebilir kuru madde, kuru madde tüketimi ve nispi yem değeri açısından genotipler ve yıllar arasındaki farklılı̆ğn istatistiksel olarak \%1 seviyesinde önemli olduğu, bin tane ağırlığı ve ham protein verimi açışından ise yıllar arasındaki farklılığın istatistiksel olarak önemli olmadı $\breve{g} 1$ sadece genotipler arasındaki farklılığın ise $\% 1$ seviyesinde önemli olduğu görülmektedir.

\section{Tohum ve Kes Verimleri (kg da $\left.{ }^{-1}\right)$}

Adi fi $\breve{g}$ hat ve çeşitlerinde tespit edilen tohum ve kes verimlerine ait ortalamalar Çizelge 3 'te verilmiştir. Çizelge 3 'te görüldüğü gibi; en yüksek tohum verimi $94.8 \mathrm{~kg} \mathrm{da}^{-1}$ ile GAP-2604 genotipinden elde edilmiştir. Bu genotipi $75.4 \mathrm{~kg}$ $\mathrm{da}^{-1}$ ile Soner çeşidi izlemiştir.

En yüksek kes verimi de $289.8 \mathrm{~kg} \mathrm{da}^{-1}$ ile Soner çeşidinden elde edilmiş ve bu çeşidi istatistiksel olarak aynı grupta olan Kubilay-82 ve Uludağ çeşitleri izlemiştir.

Yıllara göre bakıldı̆̆ında, en yüksek tohum verimi ortalaması $\left(60.9 \mathrm{~kg} \mathrm{da}^{-1}\right)$ ile en yüksek kes verimi ortalamasının $\left(216.8 \mathrm{~kg} \mathrm{da}^{-1}\right) 2014$ yılında elde edildiği görülmektedir.

Her genotipin çevre koşullarına göstereceğ $\mathrm{i}$ tepki farklı olduğundan, genotipler arasında istatistiksel farklılıkların olması beklenen bir durumdur.

Ancak 2014 yılında alınan toplam yă̆ışı 2015 yılına göre daha düşük olması ve 2014 yılında daha yüksek tohum ve kes verimi alınmış olması bir çelişki olarak görülebilir. Her ne kadar 2014 yılının ilk altı ayında daha yüksek yağış alınmış olsa da özellikle bitkilerin çiçeklenme ve meyve tutma dönemi olan Mayıs ve Haziran aylarında bölgenin 2015 yılına nazaran daha fazla yağış aldı ğ 1 görülmektedir (Çizelge 2).

Bu durum 2014 yılında daha yüksek tohum ve kes verimi elde edilmesine sebebiyet vermiştir. 
Çizelge 3. Adi fiğ genotiplerinde saptanan tohum verimi ve kes verimi

\begin{tabular}{|c|c|c|c|c|c|c|c|}
\hline \multirow[b]{2}{*}{ No } & \multirow[b]{2}{*}{ Çeşitler } & \multicolumn{3}{|c|}{ Tohum Verimi $\left(\mathrm{kg} \mathrm{da}^{-1}\right)$} & \multicolumn{3}{|c|}{ Kes Verimi $\left(\mathrm{kg} \mathrm{da}^{-1}\right)$} \\
\hline & & 2014 & 2015 & Ortalama & 2014 & 2015 & Ortalama \\
\hline 1 & HAT-1 & 67.5 & 62.7 & $65.1 \mathrm{~b}-\mathrm{d} * *$ & 161.3 & 157.1 & $159.2 \mathrm{gh}^{* *}$ \\
\hline 2 & HAT-2 & 42.7 & 38.2 & $40.4 \mathrm{i}$ & 142.7 & 138.7 & $140.7 \mathrm{~h}$ \\
\hline 3 & HAT-7 & 56.0 & 49.8 & $52.9 \mathrm{e}-\mathrm{g}$ & 197.6 & 187.1 & $192.3 \mathrm{f}$ \\
\hline 4 & HAT-8 & 64.3 & 58.2 & $61.3 \mathrm{c}-\mathrm{e}$ & 198.9 & 184.0 & $191.4 \mathrm{f}$ \\
\hline 5 & HAT-13 & 41.5 & 36.0 & $38.8 \mathrm{i}$ & 152.1 & 143.9 & $148.0 \mathrm{~h}$ \\
\hline 6 & HAT-17 & 70.2 & 55.7 & $62.9 \mathrm{c}-\mathrm{e}$ & 194.1 & 180.2 & $187.2 \mathrm{fg}$ \\
\hline 7 & Dicle & 46.5 & 45.5 & $46.0 \mathrm{f}-\mathrm{i}$ & 241.3 & 212.4 & 226.9 de \\
\hline 8 & Görkem & 55.2 & 50.2 & $52.7 \mathrm{e}-\mathrm{h}$ & 271.9 & 240.9 & $256.4 \mathrm{~b}-\mathrm{d}$ \\
\hline 9 & Kralkızı & 46.8 & 37.8 & $42.3 \mathrm{hi}$ & 106.8 & 104.7 & $105.7 \mathrm{i}$ \\
\hline 10 & Alper & 53.0 & 55.3 & $54.2 \mathrm{ef}$ & 207.7 & 194.2 & 200.9 ef \\
\hline 11 & Soner & 76.7 & 74.2 & $75.4 \mathrm{~b}$ & 315.8 & 263.8 & $289.8 \mathrm{a}$ \\
\hline 12 & Selçuk-99 & 44.7 & 41.2 & $42.9 \mathrm{~g}-\mathrm{i}$ & 257.7 & 238.4 & $248.1 \mathrm{~cd}$ \\
\hline 13 & Cumhuriyet-99 & 64.2 & 58.5 & $61.3 \mathrm{c}-\mathrm{e}$ & 271.4 & 233.3 & $252.4 \mathrm{~b}-\mathrm{d}$ \\
\hline 14 & Kubilay-82 & 66.0 & 54.8 & $60.4 c-e$ & 288.8 & 270.7 & $279.7 \mathrm{ab}$ \\
\hline 15 & GAP 61721 & 62.3 & 55.2 & $58.8 \mathrm{de}$ & 212.4 & 188.2 & 200.3 ef \\
\hline 16 & GAP 2604 & 101.0 & 88.7 & $94.8 \mathrm{a}$ & 194.7 & 190.9 & $192.8 \mathrm{f}$ \\
\hline 17 & GAP 2490 & 60.7 & 57.0 & $58.8 \mathrm{de}$ & 191.8 & 176.9 & $184.3 \mathrm{fg}$ \\
\hline 18 & GAP 59998 & 49.3 & 41.7 & $45.5 \mathrm{f}-\mathrm{i}$ & 223.4 & 184.4 & 203.9 ef \\
\hline 19 & Uludağ & 74.8 & 66.2 & $70.5 \mathrm{bc}$ & 279.2 & 244.2 & $261.7 \mathrm{a}-\mathrm{c}$ \\
\hline 20 & Özveren & 61.0 & 57.3 & $59.2 \mathrm{de}$ & 211.1 & 192.9 & 202.0 ef \\
\hline \multirow[t]{2}{*}{21} & Alınoğlu-2001 & 74.2 & 64.2 & $69.2 \mathrm{~b}-\mathrm{d}$ & 232.0 & 180.0 & 206.0 ef \\
\hline & Ortalama & $60.9 \mathrm{~A}^{* *}$ & $54.7 \mathrm{~B}$ & 57.8 & $216.8 \mathrm{~A}^{* *}$ & 195.6 B & 206.2 \\
\hline
\end{tabular}

**) $\% 1$ Seviyesinde önemli, $\mathrm{CV}_{\text {(Tohum) }}: \% 8.53, \mathrm{CV}_{\text {(Kes) }}: \% 7.13$

Yapılan benzer çalışmalarda tohum verimi; Temel ve Tan (2002) tarafından $69.0 \mathrm{~kg} \mathrm{da}{ }^{-1}$, Karadağ ve Büyükburç (2004) tarafından 57.7-80.1 $\mathrm{kg} \mathrm{da}^{-1}$, Çil ve ark. (2006) tarafından $212-384 \mathrm{~kg} \mathrm{da}^{-}$ ${ }^{1}$, Erdurmuş ve ark. (2010) tarafından 203.1-315.3 $\mathrm{kg} \mathrm{da}^{-1}$, Kökten (2011) tarafından $78.0 \mathrm{~kg} \mathrm{da}^{-1}$, Babat ve Anlarsal (2011) tarafından 40.28-170.8 kg da-1, Seydoşoğlu (2014) tarafından 92.2-293.7 $\mathrm{kg} \mathrm{da}^{-1} \mathrm{ve}$ Gül ve ark. (2015) tarafından $151.7 \mathrm{~kg} \mathrm{da}^{-1}$ olarak tespit edilmiştir.

Kes verimi ise Temel ve Tan (2002) tarafindan $317.6 \mathrm{~kg} \mathrm{da}{ }^{-1}$, Karadağ ve Büyükburç (2004) tarafından 188.4-309.2 kg da ${ }^{-1}$, Kökten (2011) tarafından $242.7 \mathrm{~kg} \mathrm{da}^{-1}$, Babat ve Anlarsal (2011) tarafından 170.0-405.0 $\mathrm{kg} \mathrm{da}^{-1}$, Gül ve ark. (2015) tarafından ise $314.8 \mathrm{~kg} \mathrm{da}^{-1}$ olarak elde edildiği bildirilmiştir.

Tohum ve kes verimi ile ilgili olarak elde edilen bulguların, soğuk ekolojilerden elde edilen (Temel ve Tan, 2002; Karadağ ve Büyükburç, 2004; Kökten, 2011) bulgular ile benzerlik gösterirken, iklimi sıcak geçen ekolojilerden elde edilen bulgulardan daha düşük olduğu (Çil ve ark., 2006; Erdurmuş ve ark., 2010; Babat ve Anlarsal, 2011; Seydoşoğlu, 2014; Gül ve ark., 2015) görülmektedir. 


\section{Bin tane ağırlı̆̆ı (g) ve ham kül oranı (\%)}

Adi fiğ hat ve çeşitlerinde tespit edilen bin tane ağırlığı ve ham kül oranlarına ait ortalamalar Çizelge 4 'te verilmiştir. Çizelge 4'te görüldüğü gibi; en yükssek bin tane ağırlığı $56.3 \mathrm{~g}$ ile GAP-2490 genotipinden elde edilmiştir. Bunu istatistiksel olarak aynı grupta olan GAP-59998, Alınoğlu-2001, Özveren, Cumhuriyet-99, Hat-8 ve Hat-17 genotipleri izlemiştir. En düşük ham kül oranı da \%9.4 ile Hat-13 ve \%9.5 ile Selçuk-99 genotiplerinden elde edilmiştir. Bin tane ağırlı̆̆ 1 açısından yıllar arasında istatistiksel bir farklılık görülmemiş olup, en düşük ham kül oranının da (\% 10.8) 2014 y1lında edildiği görülmektedir. Bin tane ağırlığ tohum verimi arasında pozitif bir ilişki bulunmaktadır (Çizelge 9). Dolaysıyla tohum veriminin yüksek olarak elde edildiği çalışmalarda bin tane ağırlığı da yüksek çıkmaktadır. Ham kül oranı ile kes verimi arasında ise negatif bir ilişki bulunmaktadır (Çizelge 9). Örneğin kes veriminin düşük olduğu 2015 yılında ham kül oranının en yüksek değerini verdiği görülmektedir.

Yapılan benzer çalışmalarda bin tane ağırlığı; Karadağ ve Büyükburç (2004) tarafından 56.9-69.7 g, Çil ve ark. (2006) tarafından 36.7-88.6 g, Erdurmuş ve ark. (2010) tarafından 57.9-83.1 g, Kökten (2011) tarafından $55.1 \mathrm{~g}$, Babat ve Anlarsal (2011) tarafından 49.30-62.67 kg da ${ }^{-1}$, Seydoşoğlu (2014) tarafından 46.5-84.5 kg da ${ }^{-1}$ ve Gül ve ark. (2015) tarafından $50.59 \mathrm{~g}$ olarak bildirilmiştir. Fiğ samanında ham kül oranı, Bayram (1997) tarafından \%8.84 ve Şehu ve ark. (1998) tarafından ise \%9.55 olarak bildirilmiştir.

Çizelge 4. Adi fiğ genotiplerinde saptanan bin tane ağırlı̆̆ı ve ham kül oranları

\begin{tabular}{|c|c|c|c|c|c|c|c|}
\hline \multirow[b]{2}{*}{ No } & \multirow[b]{2}{*}{ Çeşitler } & \multicolumn{3}{|c|}{ Bin Tane Ağırlığı (g) } & \multicolumn{3}{|c|}{ Ham Kül (\%) } \\
\hline & & 2014 & 2015 & Ortalama & 2014 & 2015 & Ortalama \\
\hline 1 & HAT-1 & 48.9 & 48.7 & $48.8 \mathrm{~d}-\mathrm{f} * *$ & 12.2 & 12.5 & $12.4 \mathrm{~b}-\mathrm{e}^{* *}$ \\
\hline 2 & HAT-2 & 40.0 & 39.9 & $39.9 \mathrm{hi}$ & 14.2 & 12.0 & $13.1 \mathrm{a}-\mathrm{c}$ \\
\hline 3 & HAT-7 & 45.8 & 45.4 & $45.6 \mathrm{e}-\mathrm{g}$ & 15.3 & 15.3 & $15.3 \mathrm{a}$ \\
\hline 4 & HAT-8 & 53.7 & 53.5 & $53.6 \mathrm{a}-\mathrm{d}$ & 13.9 & 14.4 & $14.1 \mathrm{ab}$ \\
\hline 5 & HAT-13 & 37.6 & 38.2 & $37.9 \mathrm{i}$ & 8.5 & 10.3 & $9.4 \mathrm{f}$ \\
\hline 6 & HAT-17 & 53.6 & 53.5 & $53.6 \mathrm{a}-\mathrm{d}$ & 10.6 & 14.9 & $12.8 \mathrm{a}-\mathrm{d}$ \\
\hline 7 & Dicle & 46.1 & 45.8 & $46.0 \mathrm{e}-\mathrm{g}$ & 9.8 & 13.8 & $11.8 \mathrm{~b}-\mathrm{f}$ \\
\hline 8 & Görkem & 42.1 & 42.0 & $42.1 \mathrm{~g}-\mathrm{i}$ & 9.9 & 10.0 & 9.9 ef \\
\hline 9 & Kralkızı & 46.4 & 44.6 & $45.5 \mathrm{e}-\mathrm{g}$ & 10.3 & 11.3 & $10.8 \mathrm{c}-\mathrm{f}$ \\
\hline 10 & Alper & 49.5 & 49.4 & 49.4 c-e & 9.5 & 12.8 & $11.2 \mathrm{c}-\mathrm{f}$ \\
\hline 11 & Soner & 43.8 & 43.3 & $43.6 \mathrm{f}-\mathrm{h}$ & 9.9 & 9.5 & $9.7 \mathrm{ef}$ \\
\hline 12 & Selçuk-99 & 42.5 & 42.6 & $42.5 \mathrm{~g}-\mathrm{i}$ & 8.8 & 10.1 & $9.5 \mathrm{f}$ \\
\hline 13 & Cumhuriyet-99 & 52.4 & 52.0 & $52.2 \mathrm{a}-\mathrm{d}$ & 9.1 & 11.3 & $10.2 \mathrm{~d}-\mathrm{f}$ \\
\hline 14 & Kubilay-82 & 49.8 & 49.2 & $49.5 \mathrm{c}-\mathrm{e}$ & 11.8 & 8.1 & 9.9 ef \\
\hline 15 & GAP 61721 & 50.4 & 50.2 & $50.3 \mathrm{~b}-\mathrm{e}$ & 9.6 & 10.0 & 9.8 ef \\
\hline 16 & GAP 2604 & 45.6 & 45.9 & $45.7 \mathrm{e}-\mathrm{g}$ & 11.2 & 10.0 & $10.6 \mathrm{c}-\mathrm{f}$ \\
\hline 17 & GAP 2490 & 56.4 & 56.2 & $56.3 \mathrm{a}$ & 10.0 & 12.7 & $11.3 \mathrm{~b}-\mathrm{f}$ \\
\hline 18 & GAP 59998 & 55.0 & 54.8 & $54.9 \mathrm{ab}$ & 10.3 & 13.9 & $12.1 \mathrm{~b}-\mathrm{f}$ \\
\hline 19 & Uludağ & 45.8 & 45.0 & $45.4 \mathrm{e}-\mathrm{g}$ & 10.1 & 10.8 & $10.4 \mathrm{c}-\mathrm{f}$ \\
\hline 20 & Özveren & 53.8 & 54.0 & $53.9 \mathrm{a}-\mathrm{d}$ & 10.4 & 12.1 & $11.2 \mathrm{c}-\mathrm{f}$ \\
\hline \multirow[t]{2}{*}{21} & Alınoğlu-2001 & 53.7 & 54.6 & $54.2 \mathrm{a}-\mathrm{c}$ & 10.4 & 11.1 & $10.8 \mathrm{c}-\mathrm{f}$ \\
\hline & Ortalama & 48.2 ÖD & 48.0 & 48.1 & $10.8 \mathrm{~B} * *$ & $11.8 \mathrm{~A}$ & 11.3 \\
\hline
\end{tabular}

**) \%1 Seviyesinde önemli, ÖD: Önemli değil, $\mathrm{CV}_{(\mathrm{BDA})}: \% 5.12, \mathrm{CV}_{(\mathrm{Kül})}: \% 11.75$ 


\section{Ham Protein Oranı (\%) ve Ham Protein Verimi $\left(\mathrm{kg} \mathrm{da}^{-1}\right)$}

Adi fĭ̆ çeşitlerinde tespit edilen ham protein oranları ve ham protein verimlerine ait ortalamalar Çizelge 5'te verilmiştir. Çizelge 5'te görüldüğü gibi; en yüksek ham protein oranı \%12.4 ile GAP-61721 genotipinden elde edilmiştir. En yüksek ham protein verimi de $31.1 \mathrm{~kg} \mathrm{da}^{-1}$ ile Kubilay-82 genotipinden elde edilirken, bu genotipi istatistiksel olarak aynı grupta yer alan Görkem, Uludağ, Soner, Selçuk-99 ve Cumhuriyet-99 genotipleri izlemiştir. Yıllara göre bakıldığında, ham protein verimi açısından yıllar arasında istatistiksel bir farklılık görülmemiş olup, en yüksek ham protein oranı ortalaması da \%10.9 ile 2015 yılında elde edildiği görülmektedir.
Ham protein oranı ile tohum verimi arasında negatif bir ilişki bulunmaktadır. Dolaysıyla tohum veriminin yüksek elde edildiği 2014 yılında daha düşük ham protein oranı elde edilmiştir. Genotiplerin ham protein verimi arasındaki farklılığı doğrudan kes verimi ve ham protein oranı ile ilgilidir (Çizelge 9). Çünkü ham protein verimi, kes verimi ile ham protein oranının çarpılması ile elde edilen bir değerdir.

Fiğ samanında ham protein oranı ile ilgili olarak elde edilen bulguların Bayram (1997) tarafından $\% 10.44$ ve Şehu ve ark. (1998) tarafindan \%9.34 olarak elde edilen bulgular ile benzerlik gösterdiğ $i$ görülmektedir.

Çizelge 5. Adi fiğ genotiplerinde saptanan ham protein oranı ve ham protein verimi

\begin{tabular}{|c|c|c|c|c|c|c|c|}
\hline \multirow[b]{2}{*}{ No } & \multirow[b]{2}{*}{ Çeşitler } & \multicolumn{3}{|c|}{ Ham Protein Oranı (\%) } & \multicolumn{3}{|c|}{ Ham Protein Verimi $\left(\mathrm{kg} \mathrm{da}^{-1}\right)$} \\
\hline & & 2014 & 2015 & Ortalama & 2014 & 2015 & Ortalama \\
\hline 1 & HAT-1 & 9.3 & 11.8 & 10.6 a-d** & 15.0 & 18.6 & 16.8 ef** \\
\hline 2 & HAT-2 & 11.3 & 11.1 & $11.2 \mathrm{a}-\mathrm{d}$ & 16.1 & 15.5 & $15.8 \mathrm{ef}$ \\
\hline 3 & HAT-7 & 9.1 & 12.8 & 10.9 a-d & 17.9 & 24.0 & $20.9 \mathrm{de}$ \\
\hline 4 & HAT-8 & 8.9 & 7.2 & $8.1 \mathrm{e}$ & 17.8 & 13.2 & $15.5 \mathrm{ef}$ \\
\hline 5 & HAT-13 & 10.9 & 9.3 & $10.1 \mathrm{a}-\mathrm{e}$ & 16.7 & 13.3 & $15.0 \mathrm{ef}$ \\
\hline 6 & HAT-17 & 9.9 & 12.5 & $11.2 \mathrm{a}-\mathrm{d}$ & 19.3 & 22.5 & $20.9 \mathrm{de}$ \\
\hline 7 & Dicle & 7.0 & 11.1 & $9.1 \mathrm{c}-\mathrm{e}$ & 16.9 & 23.7 & $20.3 \mathrm{de}$ \\
\hline 8 & Görkem & 12.5 & 11.1 & $11.8 \mathrm{ab}$ & 34.1 & 26.7 & $30.4 \mathrm{ab}$ \\
\hline 9 & Kralkızı & 10.6 & 12.3 & $11.4 \mathrm{a}-\mathrm{c}$ & 11.3 & 12.9 & $12.1 \mathrm{f}$ \\
\hline 10 & Alper & 9.4 & 11.0 & $10.2 \mathrm{a}-\mathrm{e}$ & 19.5 & 21.3 & $20.4 \mathrm{de}$ \\
\hline 11 & Soner & 8.9 & 9.5 & $9.2 \mathrm{c}-\mathrm{e}$ & 28.1 & 25.0 & $26.5 \mathrm{a}-\mathrm{d}$ \\
\hline 12 & Selçuk-99 & 10.4 & 10.1 & $10.3 \mathrm{a}-\mathrm{e}$ & 26.8 & 24.2 & $25.5 \mathrm{a}-\mathrm{d}$ \\
\hline 13 & Cumhuriyet-99 & 10.1 & 9.9 & $10.0 \mathrm{a}-\mathrm{e}$ & 27.5 & 23.0 & $25.3 \mathrm{a}-\mathrm{d}$ \\
\hline 14 & Kubilay-82 & 10.8 & 11.5 & $11.1 \mathrm{a}-\mathrm{d}$ & 31.1 & 31.0 & $31.1 \mathrm{a}$ \\
\hline 15 & GAP 61721 & 10.6 & 14.2 & $12.4 \mathrm{a}$ & 22.5 & 26.6 & $24.6 \mathrm{~b}-\mathrm{d}$ \\
\hline 16 & GAP 2604 & 6.6 & 11.0 & $8.8 \mathrm{de}$ & 12.8 & 21.0 & $16.9 \mathrm{ef}$ \\
\hline 17 & GAP 2490 & 8.4 & 10.1 & $9.2 \mathrm{c}-\mathrm{e}$ & 16.2 & 17.8 & $17.0 \mathrm{ef}$ \\
\hline 18 & GAP 59998 & 11.3 & 8.9 & $10.1 \mathrm{a}-\mathrm{e}$ & 25.3 & 16.4 & $20.9 \mathrm{de}$ \\
\hline 19 & Uludağ & 10.4 & 12.1 & $11.2 \mathrm{a}-\mathrm{d}$ & 28.9 & 29.5 & $29.2 \mathrm{a}-\mathrm{c}$ \\
\hline 20 & Özveren & 11.9 & 11.6 & $11.8 \mathrm{ab}$ & 25.1 & 22.4 & $23.8 \mathrm{~cd}$ \\
\hline \multirow[t]{2}{*}{21} & Alınoğlu-2001 & 10.2 & 9.4 & $9.8 \mathrm{~b}-\mathrm{e}$ & 23.6 & 16.9 & $20.2 \mathrm{de}$ \\
\hline & Ortalama & $9.9 \mathrm{~B}^{* *}$ & $10.9 \mathrm{~A}$ & 10.4 & $21.5^{\mathrm{OD}}$ & 21.2 & 21.4 \\
\hline
\end{tabular}

**) \%1 Seviyesinde önemli, ÖD: Önemli değil, $\mathrm{CV}_{(\mathrm{HP})}: \% 11.29, \mathrm{CV}_{(\mathrm{HPV})}: \% 14.12$ 
Asit deterjanda ve nötral deterjanda çözünmeyen lif oranları $(\%)$

Adi fĭ ğ genotiplerinde tespit edilen ADF ve NDF ortalamaları Çizelge 6'da verilmiştir. Çizelge 6 'da görüldü̆gü gibi; en düşük $\mathrm{ADF}$ oranı \%29.5 Alper çeşidinden ve en düşük NDF oranı ise $\% 42.0$ ile Hat-1 genotipinden elde edilmiştir. Yıllara göre bakıldığında en düşük $\mathrm{ADF}$ oranı (\%28.2) ve en düşük NDF oranının (\%42.7) 2014 yılında elde edildiği görülmektedir. ADF ve NDF ile ham protein oranı arasında pozitif bir ilişki bulunmaktadır (Çizelge 9). Ham protein oranının en yüksek değerini verdiği 2015 yılında ADF ve NDF'nin de en yüksek değerini verdiği görülmektedir.

Çizelge 6. Adi fiğ genotiplerinde saptanan ADF ve NDF oranları

\begin{tabular}{|c|c|c|c|c|c|c|c|}
\hline \multirow[b]{2}{*}{ No } & \multirow[b]{2}{*}{ Çeşitler } & \multicolumn{3}{|c|}{$\operatorname{ADF}(\%)$} & \multicolumn{3}{|c|}{ NDF (\%) } \\
\hline & & 2014 & 2015 & Ortalama & 2014 & 2015 & Ortalama \\
\hline 1 & HAT-1 & 25.3 & 35.8 & $30.5 \mathrm{bc} * *$ & 37.6 & 46.4 & $42.0 \mathrm{e}^{* *}$ \\
\hline 2 & HAT-2 & 28.1 & 42.5 & $35.3 \mathrm{ab}$ & 40.5 & 53.3 & 46.9 a-e \\
\hline 3 & HAT-7 & 26.0 & 39.9 & $32.9 \mathrm{a}-\mathrm{c}$ & 38.6 & 49.0 & $43.8 \mathrm{de}$ \\
\hline 4 & HAT-8 & 32.4 & 35.8 & $34.1 \mathrm{a}-\mathrm{c}$ & 48.6 & 47.0 & 47.8 a-e \\
\hline 5 & HAT-13 & 27.7 & 43.2 & $35.4 \mathrm{ab}$ & 42.4 & 58.2 & $50.3 \mathrm{a}-\mathrm{c}$ \\
\hline 6 & HAT-17 & 28.7 & 38.5 & $33.6 \mathrm{a}-\mathrm{c}$ & 41.5 & 49.7 & $45.6 \mathrm{a}-\mathrm{e}$ \\
\hline 7 & Dicle & 26.6 & 37.9 & $32.2 \mathrm{a}-\mathrm{c}$ & 43.7 & 50.8 & $47.3 \mathrm{a}-\mathrm{e}$ \\
\hline 8 & Görkem & 31.0 & 42.9 & $36.9 \mathrm{a}$ & 46.4 & 54.0 & $50.2 \mathrm{a}-\mathrm{c}$ \\
\hline 9 & Kralkızı & 27.3 & 37.1 & $32.2 \mathrm{a}-\mathrm{c}$ & 43.2 & 47.7 & $45.4 \mathrm{~b}-\mathrm{e}$ \\
\hline 10 & Alper & 27.2 & 31.8 & $29.5 \mathrm{c}$ & 42.9 & 49.5 & $46.2 \mathrm{a}-\mathrm{e}$ \\
\hline 11 & Soner & 26.9 & 44.9 & $35.9 \mathrm{ab}$ & 44.8 & 58.0 & $51.4 \mathrm{a}$ \\
\hline 12 & Selçuk-99 & 33.0 & 40.1 & $36.5 \mathrm{a}$ & 46.4 & 51.4 & 48.9 a-d \\
\hline 13 & Cumhuriyet-99 & 28.1 & 36.6 & $32.4 \mathrm{a}-\mathrm{c}$ & 44.2 & 49.1 & 46.7 a-e \\
\hline 14 & Kubilay-82 & 30.3 & 44.3 & $37.3 \mathrm{a}$ & 45.7 & 56.6 & $51.1 \mathrm{ab}$ \\
\hline 15 & GAP 61721 & 28.1 & 40.1 & $34.1 \mathrm{a}-\mathrm{c}$ & 43.3 & 54.5 & 48.9 a-d \\
\hline 16 & GAP 2604 & 28.0 & 43.6 & $35.8 \mathrm{ab}$ & 41.5 & 55.5 & $48.5 \mathrm{a}-\mathrm{d}$ \\
\hline 17 & GAP 2490 & 32.8 & 39.9 & $36.3 \mathrm{a}$ & 45.7 & 51.8 & $48.7 \mathrm{a}-\mathrm{d}$ \\
\hline 18 & GAP 59998 & 25.3 & 38.9 & $32.1 \mathrm{a}-\mathrm{c}$ & 38.9 & 50.9 & $44.9 \mathrm{c}-\mathrm{e}$ \\
\hline 19 & Uludağ & 27.0 & 41.5 & $34.3 \mathrm{a}-\mathrm{c}$ & 42.0 & 50.3 & $46.1 \mathrm{a}-\mathrm{e}$ \\
\hline 20 & Özveren & 26.3 & 40.4 & $33.3 \mathrm{a}-\mathrm{c}$ & 38.9 & 49.9 & 44.4 c-e \\
\hline \multirow[t]{2}{*}{21} & Alınoğlu-2001 & 26.3 & 39.4 & $32.8 \mathrm{a}-\mathrm{c}$ & 40.2 & 52.2 & $46.2 \mathrm{a}-\mathrm{e}$ \\
\hline & Ortalama & $28.2 \mathrm{~B}^{* *}$ & $39.8 \mathrm{~A}$ & 34.0 & $42.7 \mathrm{~B}^{* *}$ & $51.7 \mathrm{~A}$ & 47.2 \\
\hline
\end{tabular}

**) \%1 Seviyesinde önemli, $\mathrm{CV}_{(\mathrm{ADF})}: \% 7.60, \mathrm{CV}_{(\mathrm{NDF})}: \% 5.86$

Bayram (1997) tarafından fĭg samanında NDF oranı \%62.63, Şehu ve ark. (1998) tarafından fĭg samanında ADF oranı \%43.35, NDF oranı \%65.44 olarak elde edildiği bildirilmiştir. ADF ve NDF oranlarındaki farklılıklar doğrudan biçim zamanı ile ilgilidir. Erken yapılan biçimlerde ADF ve NDF oranları daha düşük, geç yapılan biçimlerde ise ADF ve NDF oranları daha yüksek çıkmaktadır. Ayrıca ADF 
ve NDF tespitinde kullanılan yöntemlerin farklılı̆̆ ADF ve NDF sonuçlarının farklı çıkmasına sebebiyet verebilmektedir.

\section{Sindirilebilir kuru madde ve kuru madde tüketimi $(\%)$}

Adi fiğ genotiplerinde tespit edilen sindirilebilir kuru madde ve kuru madde tüketimine ait ortalamalar
Çizelge 7'de verilmiştir. Çizelge 7'de görüldüğü gibi; en yüksek SKM oranı \%65.9 ile Alper çeşidinden elde edilirken, en düşük SKM oranı Görkem, Selçuk-99, Kubilay-82 ve GAP 2490 genotiplerinden elde edilmiştir.

En yükssek SKM oranı ortalaması \%66.9 ile 2014 yılında elde edilirken, genotiplerin iki yıllık SKM oranı ortalaması da \%62.4 olarak tespit edilmiştir.

Çizelge 7. Adi fiğ genotiplerinde saptanan SKM ve KMT oranları

\begin{tabular}{|c|c|c|c|c|c|c|c|}
\hline \multirow[b]{2}{*}{ No } & \multirow[b]{2}{*}{ Çeşitler } & \multicolumn{3}{|c|}{ Sindirilebilir Kuru Madde (\%) } & \multicolumn{3}{|c|}{ Kuru Madde Tüketimi (\%) } \\
\hline & & 2014 & 2015 & Ortalama & 2014 & 2015 & Ortalama \\
\hline 1 & HAT-1 & 69.2 & 61.0 & $65.1 \mathrm{ab}^{* *}$ & 3.20 & 2.59 & $2.89 \mathrm{a}^{* *}$ \\
\hline 2 & HAT-2 & 67.0 & 55.8 & $61.4 \mathrm{bc}$ & 3.01 & 2.25 & $2.63 \mathrm{a}-\mathrm{e}$ \\
\hline 3 & HAT-7 & 68.7 & 57.9 & $63.3 \mathrm{a}-\mathrm{c}$ & 3.11 & 2.45 & $2.78 \mathrm{ab}$ \\
\hline 4 & HAT-8 & 63.7 & 61.0 & $62.3 \mathrm{a}-\mathrm{c}$ & 2.47 & 2.55 & $2.51 \mathrm{~b}-\mathrm{e}$ \\
\hline 5 & HAT-13 & 67.3 & 55.2 & $61.3 \mathrm{bc}$ & 2.84 & 2.06 & $2.45 \mathrm{~b}-\mathrm{e}$ \\
\hline 6 & HAT-17 & 66.5 & 58.9 & $62.7 \mathrm{a}-\mathrm{c}$ & 2.90 & 2.41 & $2.66 \mathrm{a}-\mathrm{e}$ \\
\hline 7 & Dicle & 68.2 & 59.4 & $63.8 \mathrm{a}-\mathrm{c}$ & 2.75 & 2.36 & $2.56 \mathrm{a}-\mathrm{e}$ \\
\hline 8 & Görkem & 64.8 & 55.5 & $60.1 \mathrm{c}$ & 2.58 & 2.22 & $2.40 \mathrm{c}-\mathrm{e}$ \\
\hline 9 & Kralkızı & 67.7 & 60.0 & $63.8 \mathrm{a}-\mathrm{c}$ & 2.79 & 2.52 & $2.65 \mathrm{a}-\mathrm{e}$ \\
\hline 10 & Alper & 67.7 & 64.1 & $65.9 \mathrm{a}$ & 2.80 & 2.43 & $2.62 \mathrm{a}-\mathrm{e}$ \\
\hline 11 & Soner & 67.9 & 54.0 & $61.0 \mathrm{bc}$ & 2.68 & 2.07 & $2.38 \mathrm{de}$ \\
\hline 12 & Selçuk-99 & 63.2 & 57.7 & $60.4 \mathrm{c}$ & 2.59 & 2.33 & $2.46 \mathrm{~b}-\mathrm{e}$ \\
\hline 13 & Cumhuriyet-99 & 67.0 & 60.4 & $63.7 \mathrm{a}-\mathrm{c}$ & 2.72 & 2.44 & $2.58 \mathrm{a}-\mathrm{e}$ \\
\hline 14 & Kubilay-82 & 65.3 & 54.4 & $59.8 \mathrm{c}$ & 2.63 & 2.12 & $2.37 \mathrm{e}$ \\
\hline 15 & GAP 61721 & 67.0 & 57.6 & $62.3 \mathrm{a}-\mathrm{c}$ & 2.78 & 2.20 & $2.49 \mathrm{~b}-\mathrm{e}$ \\
\hline 16 & GAP 2604 & 67.1 & 55.0 & $61.0 \mathrm{bc}$ & 2.89 & 2.16 & $2.53 \mathrm{~b}-\mathrm{e}$ \\
\hline 17 & GAP 2490 & 63.4 & 57.8 & $60.6 \mathrm{c}$ & 2.62 & 2.32 & $2.47 \mathrm{~b}-\mathrm{e}$ \\
\hline 18 & GAP 59998 & 69.2 & 58.6 & $63.9 \mathrm{a}-\mathrm{c}$ & 3.09 & 2.36 & $2.72 \mathrm{a}-\mathrm{d}$ \\
\hline 19 & Uludağ & 67.8 & 56.6 & $62.2 \mathrm{a}-\mathrm{c}$ & 2.86 & 2.39 & $2.63 \mathrm{a}-\mathrm{e}$ \\
\hline 20 & Özveren & 68.4 & 57.4 & $62.9 \mathrm{a}-\mathrm{c}$ & 3.08 & 2.40 & $2.74 \mathrm{a}-\mathrm{c}$ \\
\hline \multirow[t]{2}{*}{21} & Alınoğlu-2001 & 68.4 & 58.2 & $63.3 \mathrm{a}-\mathrm{c}$ & 2.99 & 2.30 & $2.64 \mathrm{a}-\mathrm{e}$ \\
\hline & Ortalama & $66.9 \mathrm{~A}^{* *}$ & $57.9 \mathrm{~B}$ & 62.4 & $2.83 \mathrm{~A} * *$ & $2.33 \mathrm{~B}$ & 2.58 \\
\hline
\end{tabular}

En yüksek KMT oranı \%2.89 ile Hat-1 genotipinden elde edilirken, en düşük KMT oranı \%2.37 ile Kubilay-82 genotipinden elde edilmiştir. En yükssek
KMT oranı ortalaması $\% 2.83$ ile 2014 yllında elde edilirken, genotiplerin iki yıllık KMT oranı ortalaması $\% 2.58$ olarak tespit edilmiştir. 


\section{Nispi yem değeri}

Adi fĭg genotiplerinde tespit edilen nispi yem değerine ait ortalamalar Çizelge 8 'de verilmiştir. Çizelge 8'de görüldüğü gibi; en yüksek NYD 147.1 ile Hat-1 genotipinden elde edilirken, en düşük NYD
111.2 ile Kubilay-82 genotipinden elde edilmiştir. Yıllara göre bakıldığından en yüksek NYD 147.0 ile 2014 yılında elde edilirken, en düşük NYD 104.9 ile 2015 yılında elde edilmiştir. Genotiplerin iki yıllık NYD ortalaması 126.0 olarak tespit edilmiştir.

Çizelge 8. Adi fiğ genotiplerinde saptanan nispi yem değeri

\begin{tabular}{|c|c|c|c|c|}
\hline \multirow[b]{2}{*}{ No } & \multirow[b]{2}{*}{ Çeşitler } & \multicolumn{3}{|c|}{ Nispi Yem Değeri } \\
\hline & & 2014 & 2015 & Ortalama \\
\hline 1 & HAT-1 & 171.8 & 122.5 & $147.1 \mathrm{a}^{* *}$ \\
\hline 2 & HAT-2 & 157.0 & 97.3 & $127.1 \mathrm{a}-\mathrm{d}$ \\
\hline 3 & HAT-7 & 165.6 & 110.0 & $137.8 \mathrm{ab}$ \\
\hline 4 & HAT-8 & 122.0 & 120.7 & $121.4 \mathrm{~b}-\mathrm{d}$ \\
\hline 5 & HAT-13 & 148.7 & 88.4 & $118.5 \mathrm{~b}-\mathrm{d}$ \\
\hline 6 & HAT-17 & 149.6 & 110.3 & $129.9 \mathrm{a}-\mathrm{d}$ \\
\hline 7 & Dicle & 145.3 & 108.8 & $127.0 \mathrm{a}-\mathrm{d}$ \\
\hline 8 & Görkem & 129.8 & 95.7 & $112.7 \mathrm{~cd}$ \\
\hline 9 & Kralkızı & 146.5 & 117.1 & $131.8 \mathrm{a}-\mathrm{d}$ \\
\hline 10 & Alper & 147.2 & 120.5 & $133.9 \mathrm{a}-\mathrm{d}$ \\
\hline 11 & Soner & 141.3 & 86.6 & $113.9 \mathrm{~b}-\mathrm{d}$ \\
\hline 12 & Selçuk-99 & 126.7 & 104.4 & $115.6 \mathrm{~b}-\mathrm{d}$ \\
\hline 13 & Cumhuriyet-99 & 141.6 & 114.4 & $128.0 \mathrm{a}-\mathrm{d}$ \\
\hline 14 & Kubilay-82 & 133.0 & 89.3 & $111.2 \mathrm{~d}$ \\
\hline 15 & GAP 61721 & 144.3 & 98.3 & $121.3 \mathrm{~b}-\mathrm{d}$ \\
\hline 16 & GAP 2604 & 150.3 & 92.1 & $121.2 \mathrm{~b}-\mathrm{d}$ \\
\hline 17 & GAP 2490 & 128.9 & 104.0 & $116.5 \mathrm{~b}-\mathrm{d}$ \\
\hline 18 & GAP 59998 & 165.5 & 107.2 & $136.4 \mathrm{a}-\mathrm{c}$ \\
\hline 19 & Uludağ & 150.6 & 104.7 & $127.6 \mathrm{a}-\mathrm{d}$ \\
\hline 20 & Özveren & 163.4 & 107.1 & $135.2 \mathrm{a}-\mathrm{d}$ \\
\hline \multirow[t]{2}{*}{21} & Alınoğlu-2001 & 158.7 & 103.7 & $131.2 \mathrm{a}-\mathrm{d}$ \\
\hline & Ortalama & $147.0 \mathrm{~A}^{* *}$ & $104.9 \mathrm{~B}$ & 126.0 \\
\hline
\end{tabular}

**) \%1 Seviyesinde önemli, CV:\%9.17

ADF ve NDF oranları ile SKM, KMT ve NYD arasında negatif bir ilişki bulunmaktadır (Çizelge 9). ADF ve NDF oranlarının en yüksek değerlerini verdiği

\section{Özellikler arası ilişkiler}

Adi fĭg genotiplerinde incelenen özellikler arasında saptanan korelasyon katsayıları Çizelge 9'da verilmiştir. Çizelge 9'da görüldüğgü gibi, tohum
2015 yllında, SKM, KMT ve NYD'nin en düşük değerlerini verdiği görülmektedir.

veriminin kes verimi ile arasında çok önemli ve olumlu, bin tane ağırlığı ile arasında önemli ve olumlu ancak ham protein oranı ile arasında çok önemli ve negatif bir ilişkinin olduğu görülmektedir. 
Kes veriminin ham protein verimi ile arasında çok önemli ve olumlu, ham kül oranı ile arasında çok önemli ve negatif bir ilişki olduğu görülmektedir. Ham protein oranının ham protein verimi ve ADF ile arasında çok önemli ve olumlu, NDF ile arasında önemli ve olumlu, SKM ile arasında çok önemli ve negatif, KMT ve NYD ile arasında ise önemli ve negatif bir ilişkinin olduğu görülmektedir. Ham protein verimi ile ham kül oranı arasında çok önemli ve negatif bir ilişki olduğu görülmektedir.

Çizelge 9. Araştırmada incelenen özellikler arasında bulunan korelasyon katsayıları

\begin{tabular}{|c|c|c|c|c|c|c|c|c|c|c|}
\hline & $\mathbf{K V}$ & BDA & HPO & HPV & HK & ADF & NDF & SKM & KMT & NYD \\
\hline TV & $0.346^{* *}$ & $0.222^{*}$ & $\begin{array}{c}-0.263 \\
* *\end{array}$ & 0.163 & -0.108 & -0.173 & -0.152 & 0.173 & 0.155 & 0.168 \\
\hline KV & & 0.047 & -0.079 & $0.832 * *$ & $\begin{array}{c}-0.351 \\
* *\end{array}$ & -0.103 & 0.004 & 0.103 & -0.015 & 0.031 \\
\hline BDA & & & -0.083 & 0.007 & 0.137 & -0.099 & -0.157 & 0.099 & 0.132 & 0.113 \\
\hline HPO & & & & $0.477 * *$ & -0.026 & $0.264 * *$ & $0.189 *$ & $-0.264 * *$ & $-0.182 *$ & $-0.217^{*}$ \\
\hline HPV & & & & & $\begin{array}{c}-0.318 \\
* *\end{array}$ & 0.065 & 0.114 & -0.065 & -0.117 & -0.098 \\
\hline HK & & & & & & 0.096 & -0.051 & -0.096 & 0.033 & -0.027 \\
\hline ADF & & & & & & & $\begin{array}{c}0.918 \\
* *\end{array}$ & $-1.000 * *$ & $-0.904 * *$ & $-0.958 * *$ \\
\hline NDF & & & & & & & & $-0.918 * *$ & $-0.991 * *$ & $-0.981 * *$ \\
\hline SKM & & & & & & & & & $0.904 * *$ & $0.958 * *$ \\
\hline KMT & & & & & & & & & & $0.987 * *$ \\
\hline
\end{tabular}

*)\%5 düzeyinde önemli, **)\%1 düzeyinde önemli; TV=Tohum verimi, $\mathrm{KV}=$ Kes verimi, BDA=Bin tane ağırlığı HP=Ham protein, HPV= Ham protein verimi, HK=Ham kül

ADF ile NDF arasında çok önemli ve olumlu bir ilişki bulunmaktadır. Ancak hem ADF hem de NDF'nin SKM, KMT ve NYD ile aralarında çok önemli ve negatif bir ilişki olduğu görülmektedir. SKM'nin KMT

\section{SONUÇ}

Çalışmada; en yüksek tohum verimi GAP-2604, en yüksek kes verimi Soner, en yüksek bin tane ağırlığı GAP-2490, en düşük ham kül oranı Hat-13 ve Selçuk-99, en yüksek ham protein oranı GAP61721, en yüksek ham protein verimi Kubilay-82, en düşük ADF oranı Alper, en düşük NDF oranı Hat-1, en yüksek SKM oranı Alper, en yüksek KMT oranı Hat-

\section{KAYNAKLAR}

Açıkgöz E, 2001. Yem Bitkileri. Uludağ Üniversitesi Güçlendirme Vakfı Yayın No: 182, 95 s.

Açıkgöz E, 2011. Yem Bitkileri Yetiştiriciliği. Süt Hayvancılığı, Eğitim Merkezi Yay. Hayvancılık Serisi. ve NYD ile arasında ve KMT'nin de NYD ile arasında çok önemli ve olumlu bir ilişkinin olduğu tespit edilmiştir.

1 ve yine en yüksek NYD oranı Hat-1 genotiplerinden elde edilmiştir. Bu bilgiler ışığında dekara elde edilen tohum ve kes veriminin fazlalığından dolayı GAP-2604 ve Soner, ham protein oranının yüksekliğinden dolayı GAP-61721 ve ADF ve NDF oranlarının düşüklüğü NYD'nin yüksekliğinden dolayı Hat-1 ve Alper genotiplerinin üstün özellikler göstererek öne çıktığ1 tespit edilmiştir.

Anonim, 2017. Türkiye İstatistik Kurumu, Bitkisel Üretim İstatistikleri Veri Tabanı. http://www.tuik.gov.tr/PreTablo. do?alt_id=1001. (Erişim tarihi: 31 Aralık, 2017).

AOAC, 1990. Association of Official Analytical Chemists. Official Method of Analysis. 15th.ed. Washington, DC. USA. 66 p. 
Babat S, Anlarsal AE, 2011. Diyarbakır ekolojik koşullarında bazı adi fiğ (Vicia sativa $\mathrm{L}$.) çeşitlerinin verim ve verim öğelerinin belirlenmesi üzerine bir araştırma. Ç.Ü. Fen ve Mühendislik Bilimleri Dergisi, 26(3): 37-46.

Bayram İ, 1997. Bazı tarımsal artıkların beyaz çürükçül mantarlarla delignifiye edilerek yem değerlerinin artırılma olanaklarının araştırılması. Ankara Üniversitesi Veteriner Fakültesi Dergisi, 44: $1-9$.

Çil A, Çil AN, Yücel C, 2006. Bazı adi fiğ (Vicia sativa L.) hatlarının Harran Ovası koşullarına adaptasyonu. Harran Üniv. Ziraat Fak. Dergisi, 10(1/2): 53-61.

Er C, Başalma D, Ekiz H, Sancak C, 2011. Tarla Bitkileri-II. T.C. Anadolu Üniversitesi Yayını No:2254.

Erdurmuş C, Çeçen S, Yücel C, 2010. Antalya koşullarında bazı yaygın fĭg (Vicia sativa) hat ve çeşitlerinin verim ve verim özelliklerinin belirlenmesi. Akdeniz Üniv. Ziraat Fak. Derg,, 23(1):53-60.

Ekiz H, Altınok S, Sancak C, Sevimay CS, Kendir H, 2011. Tarla Bitkileri. Ankara Üniversitesi Ziraat Fakültesi Yayınları, Yayın No:1588, $491 \mathrm{~s}$.

Gül İ, Gül Dumlu Z, Tan M, 2015. Yerli fiğ (Vicia sativa L.)'de kimyasal gübre, ahır gübresi ve bazı toprak düzenleyicilerin ot ve tohum verimine etkileri. Iğdır Üniv. Fen Bilimleri Enstitüsü Dergisi, 5(1): 65-72.

Karadağ Y, Büyükburç U, 2004. Tokat-Kozova koşullarında farklı tohumluk miktarlarının bazı adi fiğ (Vicia sativa $\mathrm{L}$.) çeşitlerinde ot ve tohum verimine etkisi. Tarım Bilimleri Dergisi, 10(2): 149-157.

Karaman MR, 2012. Bitki Besleme. Gübretaş Rehber Kitaplar Dizisi:2. Editör: Zengin, M., Toprak ve Bitki Analiz Sonuçlarının Yorumlanmasında Temel İlkeler (Bölüm 12), $874 \mathrm{~s}$.

Kalaycı M, 2005. Örneklerle Jump Kullanımı ve Tarımsal Araştırma İçin Varyans Analiz Modelleri. Anadolu Tarımsal Araştırma Enstitüsü Müdürlüğü Yayınları, Yayın No:21.
Kökten K, 2011. Bingöl ekolojik koşullarında bazı adi fiğ (Vicia sativa L.) hat ve çeşitlerinde tohum verimi ve bazı tarımsal özelliklerin belirlenmesi. Bingöl Üniversitesi Fen Bil. Dergisi, $1(2): 81-85$

Kurt O, 2012. Tarla Bitkileri Yetiştirme Tekniği. Ondokuz Mayıs Üniversitesi Ziraat Fakültesi Ders Kitab1, No:44, 171 s.

Morrison JA, 2003. Hay and Pasture Management, Chapter 6. Illinois Agronomy Handbook, $72 \mathrm{p}$.

Seydoşoğlu S, 2014. Diyarbakır ekolojik koşullarında bazı yaygın fiğ (Vicia sativa $\mathrm{L}$.) genotiplerinin verim ve verim unsurlarının belirlenmesi. Türkiye Tarımsal Araştırmalar Dergisi, (2014)1: 117-227.

Sezen Y, 1995. Gübreler ve Gübreleme. Atatürk Üniversitesi Yayınları No:679, Ziraat Fakültesi Yayınları No:303, Erzurum, $15 \mathrm{~s}$.

Şehu A, Yalçın S, Önol AG, Koçak D, 1998. Kaba yemlerin bazı özelliklerinden yararlanarak kuzularda kuru madde tüketimi ve canlı ağırlık artışının belirlenmesi. Tr. J. of Veterinary and Animal Sicences 22: 475-483.

Temel S, Tan M, 2002. Erzurum şartlarında adi fiğ (Vicia sativa L.)'in ekim ve hasat zamanlarının belirlenmesi üzerine bir araştırma. Atatürk Üniversitesi Ziraat Fak. Dergisi, 33(4): 363-368.

Temel S, Keskin B, Yıldız V, Kır A E, 2015. Iğdır ovası taban koşullarında adi fiğ (Vicia sativa L.) çeşitlerinin kuru ot verimi ve kalitesi özelliklerinin incelenmesi. Iğdır Üni. Fen Bilimleri Enst. Der., 5(3): 67-76.

Van Soest P J, Robertson J B, Lewis B A, 1991. Methods for dietary fiber, neutral detergent fiber and non-starch polysaccharides in relation to animal nutrition. J. Dairy Sci., 74: 3583-3597. 